\title{
The Pathological Changes in Caecum in Broilers Infected with Eimeria tenella and Treated with Sapindus rarak Powder
}

\author{
Pasaribu $\mathrm{T}^{1}$, Wina $\mathrm{E}^{1}$, Setiyono $\mathrm{A}^{2}$, Sani $\mathrm{Y}^{3}$ \\ ${ }^{1}$ Indonesian Research Institute for Animal Production \\ PO Box 221, Bogor 16002, West Java, Indonesia \\ ${ }^{2}$ Bogor Agricultural University \\ ${ }^{3}$ Indonesian Research Center for Veterinary Science \\ Jl. RE Martadinata No. 30, Bogor 16114, West Java, Indonesia \\ pasaributiurma@yahoo.com
}

\begin{abstract}
Sapindus rarak (lerak) is a native plant in Indonesia from the family of Sapindaceae. This plant has bioactive compounds known as saponins and is potentially to inhibit the growth of protozoa. The purpose of this study was to determine the histopathology changes in caecum of broilers that were infected with E. tenella through their litter, followed by an addition of $S$. rarak powder (SRP) with $2.5 \mathrm{~g} / \mathrm{kg}$ in ration. A total of 90 birds consisted of 3 treatments with 3 replicates (10 birds per replicate) reared in litter system for 35 days. A completely randomized design was arranged for this experiment with R1 (Control, without coccidiostat, without SRP); R2 (Coccidiostat); R3 (SRP $2.5 \mathrm{~g} / \mathrm{kg}$ ). At 14 days old, all chickens were infected with E. tenella on the litter $(15,000$ oocysts $/ \mathrm{m})$. The parameters measured were macroscopic and microscopic changes of caecum. Chicken were dissected at day $7,10,13,16,19,21$ post-infection. The results showed that ptechiae of caecum appeared earlier on day 7 post infection in control (R1), while in SRP $2.5 \mathrm{~g} \mathrm{~kg}^{-1}$ (R3) and coccidiostat (R2) appeared on day 13 post-infection. Macroscopic and microscopic changes of caecum treated with SRP $2.5 \mathrm{~g} / \mathrm{kg}$ treatment did not show severe lesions indicating that the E. tenella did not develop in caecum. It was concluded that saponins of $S$. rarak powder (SRP) at a dose of $2.5 \mathrm{~g} / \mathrm{kg}$ inhibited the growth of $E$. tenella oocysts in the caecum of broiler chicken.
\end{abstract}

Key Words: Broiler Chicken, E. tenella, Histopathology, S. rarak Powder

\section{INTRODUCTION}

Coccidiosis is one of the leading causes of the biggest losses in the poultry industry (William et al. 1999). Coccidiosis is caused by parasites of the genus Eimeria which damage the small intestine and cecum, causing bloody diarrhea, weight loss and death of chickens (Shierly et al. 1995; Shierly 1996).

Clinically, coccidiosis in chicken is characterized by bloody stool and lethargy (Tipu et al. 2002). Coccidiosis causes indigestion and malabsorption of nutrients that causes a decrease in weight gain, egg production, and mortality up to $80-90 \%$. Additionally, coccidiosis may cause immunosuppression that cause chicken to be susceptible to infection by other agents. Economic losses caused by coccidiosis exceed $\$ 2$ billion a year (Shierly et al. 2005). Information about the losses due to coccidiosis in Indonesia is very limited. Application of antikoksidial frequently to chickhen may lead to accumulation of residue in meat or eggs, so it is necessary to find alternative to prevent of disease by using local plants to fulfill healthy and safe meat. Indonesian government program through the Ministry of Agriculture there are legislation prohibits the use of antibiotics include coccidiostat in poultry feed gradually, namely the Law on Animal Husbandry and Health No. 18 of 2009 Article 22, verses 4c.

Prevention and treatment of coccidiosis are generally carried out by administering coccidiasta which is mixing in feed. If coccidostates are given continuously to chicks they will cause resistance of coccidia to the drug (El-Sadawy et al. 2009) and leave residual in 
the meat (Jafari et al. 2007). Therefore, its need for other alternatives for a more secure product as anticoccidial for the animal itself and for meat consumer.

Sapindus rarak (lerak) is a plant that has a high content of saponin in the fruit. Secondary dominant compounds in fruit $S$. rarak are saponin and sesquiterpene (Hamburger et al. 1992; Chung et al. 1997; Wina et al. 2005).

Biological activities of saponins have hemolytic properties, expectorant, antiinflammatory and capable of inducing immunity, hipokolesteromik, anticarcinogenic. Besides, saponins shows antimicrobial properties, especially against fungal and antiprotozoa (Cheeke 2001). Saponins have the property to bind to cholesterol on the protozoan parasites and consequently kill them. If saponins can suppress the development of oocysts of Eimeria tenella, the absorption of nutrients in the gut will be increased and improve the performance of chicken. Quillaja saponin extract (Sigma S-4121) at a concentration of $75 \mathrm{ppm}$ were given to chickens lowering the number of schizonts at 4 and 7 days post-infection and at 14 days no schizont could be found (Efrizanti 2005). This indicates that the saponin has potential as anticoccidia. The use of $S$. rarak extracts in sheep could reduce up to $69 \%$ of protozoa in the rumen (Wina et al. 2005).

The objective of this present study was to evaluate the microscopic appearance of caecum of chicken infected with Emeria tenella and treated with S. rarak powder (SRP).

\section{MATERIAL AND METHODS}

\section{Experimental design}

This study was conducted in a completely randomized design (CRD) on 90 DOC (day old chicks). The birds were grouped into 3 treatments with 3 replications and each was consisted of 10 chickens. The chicken were kept in a litter system cage until 35 days. The design of treatment consists of R1 = control without coccidiostat and without SRP; R2 $=$ coccidiostat; and $\mathrm{R} 3=2.5 \mathrm{~g} \mathrm{SRP} / \mathrm{kg}$ ration. At four and fourteen days, chicken were vaccinated with strains La-Sota-strain-ND and IBD vaccines as eye drops. Multivitamines and minerals, vitachick, were gived consecutive days at 1-5 days old through drinking water. Rations were arranged to be iso protein and isocalorific with $22 \%$ crude protein and metabolizable energy of $2950 \mathrm{kcal} / \mathrm{kg}$ for starter, $20 \%$ crude protein and metabolizable energy of $3050 \mathrm{kcal} / \mathrm{kg}$ for the grower. Feed and water were given ad libitum. E. tenella inoculation carried out after 14 days old chicks by way of sprinkling of oocysts on the litter husk approximatelly 15,000 oocysts $/ \mathrm{m}^{2}$. Chicken were euthanased on day 7, 10, 13, 16, 19, 22 post-infection. The intestinal conditions were observed macroscopically and microscopically with hematoxylin eosin staining (HE).

\section{The observed parameters}

The variables measured included an overview of the cecum macroscopic lesions (pathological) and microscopic histology at day 7, 10, 13, 16, 19, 22 post-infection.

\section{RESULTS AND DISCUSSION}

\section{Macroscopic picture of cecum broiler chicken that Infected E. tenella}

Macroscopically, no specific pathological change was not found on cecum on day $7^{\text {th }}$ days post infection (pi) in birds treated with $S$. rarak powder (SRP) $2.5 \mathrm{~g} \mathrm{~kg}-1$ (R3), coccidiostat (R2) and in control (R1) groups (Figure 1a ). At $10^{\text {th }}$ days pi, cecum in the 
control treatment (R1) was found haemorhagy (Figure 1b), but no lesion was found in the birds treated with SRP $2.5 \mathrm{~g} / \mathrm{kg}$ (R3) and coccidiostat (R2). At $13^{\text {rd }}$ days pi, the control group and the birds treated with SRP $2.5 \mathrm{~g} / \mathrm{kg}$ and coccidiostat were still displayed hemorrhage (petechiae) on the cecum. (Figure 1c-d). On day $16^{\text {th }} \mathrm{pi}$, however, no abnormalities in all treatments observed. On day $19^{\text {th }}$ and $22^{\text {th }}$ pi, mild hemorrhage in the cecum and feces were visible SRP and coccidiostat treated groups. Even at day $22^{\text {th }} \mathrm{pi}$, rd spots were still found in the SRP group.
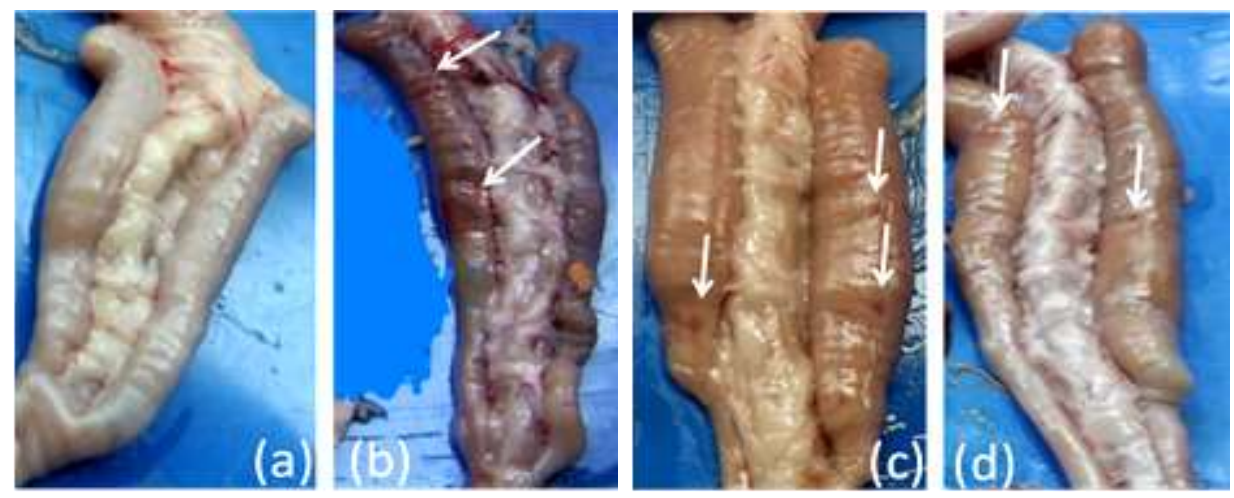

Figure 1.(a) The description of macroscopic caecum of broiler chicken that were not infected by E. Tenella; (b) The description of macroscopic caecum of broiler chicken after infection with E. tenella $\left(7^{\text {th }}\right.$ pi) at control treatment $(\mathrm{R} 1$, the arrow was haemorrhagi in the caecum. (c) Macroscopic picture of the broiler chicken caecum after infection with $E$. tenella $\left(13^{\text {th }}\right.$ pi) at SRP $2.5 \mathrm{~g} / \mathrm{kg}$ treatment $(\mathrm{R} 3)$, the arrows showed red spots on the caecum; (d) Macroscopic picture of the broiler chicken caecum after infection with $E$. tenella $\left(13^{\text {th }} \mathrm{pi}\right)$ at coccidiostat treatment $(\mathrm{R} 2)$, the arrows showed red spots on the caecum

In this study, the damage the caecum is though due to rapid growth of schizont injuring the epithelial cells and the submucosal layers of the cecum to that ultimately lead to hemorrhage. When the merozoites multiplied rapidly, so the blood could be carried away by the feces out of the body. Excessive haemorrhage can lead to the death of the infected animal, usually occurs on days 5-7 post-infection (Levine 1985). Ptechiae in the caeca mucosa of SRP and coccidiostat treated birds indicates the number of cleavage merozoites are still low due to the cecum is not haemorrhage. Compared with the control and coccidiostat treatment, SRP treatments consisted of saponin $3.02 \mathrm{~g} / \mathrm{bird}$ given for 35 days was able to inhibit the entry of oocysts into the intestinal epithelial cells or slowed the infection of chickens by E. tenella. However, when the dose of SRP be increased to 5.0 $\mathrm{g} / \mathrm{kg}$ were not recommended because it did not have a good effect on the performance, while the number of oocysts in feces declined due to higher doses of SRP (Pasaribu et al. 2014).

The severity of lesion in coccidiosis depend on the number of cell damaged, the virulence of the parasite, the type of chicken, nutritional status, other disease agents, the degree of stress, the time of reinfection, and durability at the time of the infected chickens (Levine 1985). Macroscopically, the results showed that the cecum did not show significant pathological changes in the SRP treatment. This indicates that the compound saponin from SRP sufficiently effective in suppressing the infection of E. tenella.

\section{Histopathology features of cecum on broiler chicken that infected E. tenella}

Histopathologic features in the control group (R1) infected without coccidiostat and SRP treatment suffered haemorrhagic enteritis which was characterized by inflammatory 
cell infiltration, mild haemorrhagi, and oocysts of E. tenella in the cecum on day $7^{\text {th }}$ pi (post infection) (Figure 2), Meanwhile, on chicken flocks by SRP and coccidiostat treatments no E. tenella oocysts but had mild haemorrhages.

On day $10^{\text {th }}$ pi SRP and coccidiostat treatments, there was no oocysts as in the a control group (Figure 2 and 3). At $13^{\text {th }}$ days pi, SRP and coccidiostat treatment groups showed oocysts in the cecum (Figure 4A and 4B).

On day $16^{\text {th }} \mathrm{pi}$, the oocysts were still found in the cecum of the SRP treatment, while the coccidiostat and control treatment showed mild haemorrhagi. Similarly, at day $19^{\text {th }}$ pi oocysts were still visible on SRP treatment, while the treatment of coccidiostat was visible mucosal cell infiltration of lymphocytes in the cecum, and the controls treatment showed mild haemorrhagi. On day $22^{\text {th }}$ pi was still visible oocysts in chickens with SRP and coccidiostat treatments, while control mild haemorrhagi.

If the oocysts ingested by chicken, the oocytes will grow on day 4 and 5 post infection, and will more develop on day 7 and 9 post infection. Studies showed that chicken are infected at control treatment was earlier than SRP treatment by E. tenella. This indicates that lerak saponins could inhibit infection of the oocysts of E. tenella in the cecum. Previously, in vitro studies showed that the SRP with saponin compounds could damage sporozoite of E. tenella. Damage to sporozoite enables reduced populations of $E$. tenella, which impacted on the opportunity to infect the cecum. Lerak saponins can reduce the number of protozoa in the rumen (Wina et al. 2005; Astuti et al. 2009). Therefore, SRP with saponin compounds have the potential to inhibit the growth of E. tenella.

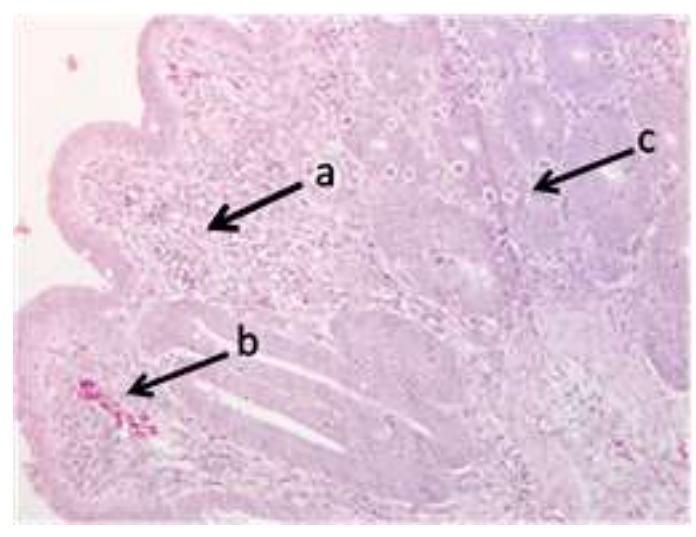

Figure 2. Histopathological lesions in the cecum in broiler chickens infected with E. tenella (control infected $7^{\text {th }}$ days pi). Arrows a (inflammatory cells), the arrow $\mathrm{b}$ (haemorrhagi mild), the arrow c (oocysts of E. tenella)

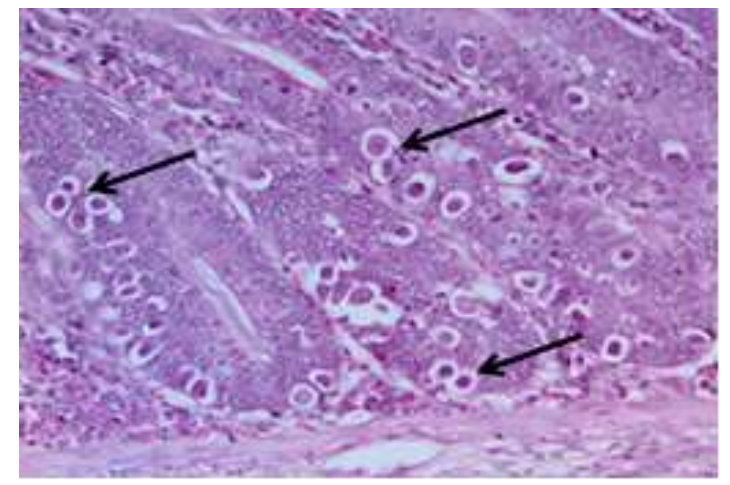

Figure 3. Histopathological lesions in the cecum of broiler chicken infected by E. tenella without coccidiostat, without SRP $2.5 \mathrm{~g} / \mathrm{kg}\left(13^{\text {th }}\right.$ days pi). Objective magnification $40 \times$; arrow (oocysts) 

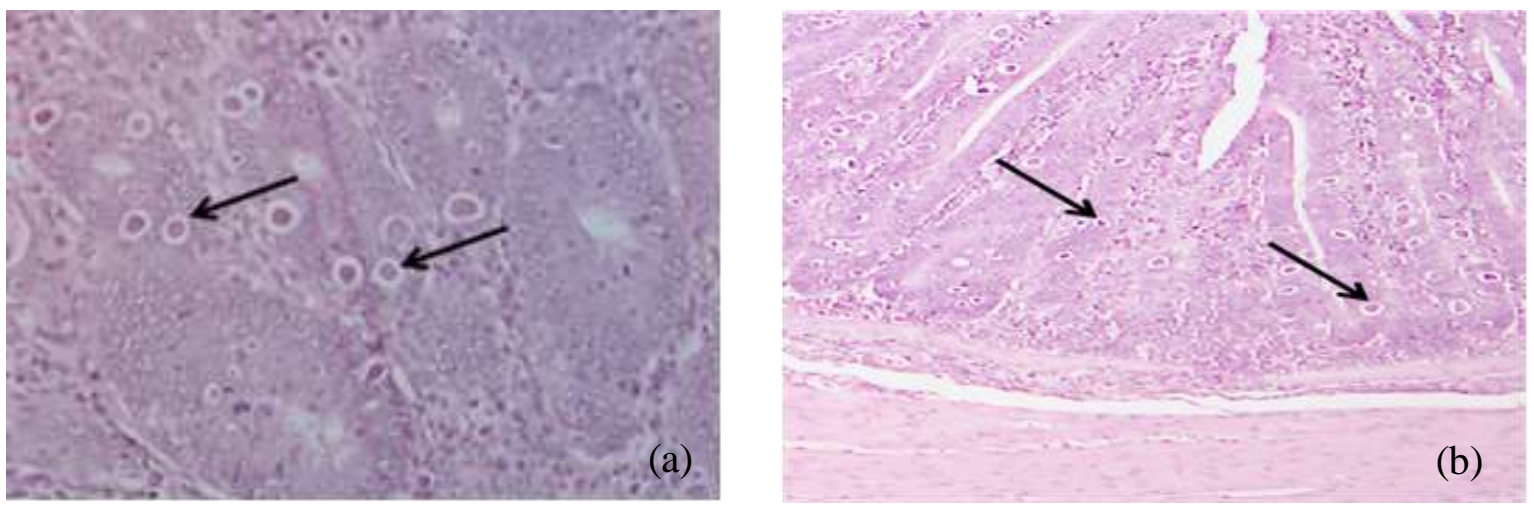

Figure 4. (a) Overview cecum lesions ( $13^{\text {th }}$ days pi) histopathological basis of broiler chickens infected by E. tenella, by SRP $2.5 \mathrm{~g} \mathrm{~kg}-1$. Objective magnification 40x; arrow (oocysts); (b) Overview cecum lesions (13 ${ }^{\text {th }}$ days pi) histopathological basis of broiler chickens infected by $E$. tenella, were given coccidiostat. Objective magnification $20 \times$; The arrow (oocysts)

Study showed that cecum had a mild damage either macroscopically or microscopically, indicating that saponin of SRP was able to inhibit the multiplication of $E$. tenella in the cecum. Wiedosari et al. (2014) reported similar results with the administration of herbal medicine to chickens. Red-ginger-extract solution as much as $1 \%$ could be used as coccidiostatin broilers (Iskandar et al. 2000). Saponins from Quillaja can stimulate antigen-presenting cells (APC) to produce proinflammatory cytokines that have the potential to stimulate immunity (Behboudi et al. 1999). This study indicates that saponins from Sapindus rarak are useful as inhibitors of multiplication of E. tenella in the cecum of broiler chickens.

\section{CONCLUSION}

Sapindus rarak powder has potencial coccidiostat activity on broiler chicken infected with Emeria tenella.

\section{REFERENCES}

Astuti DA, Wina E, Haryanto B, Suharti S. 2009. Performance and profile of some blood components of Ongole crossbred cattle fed ration containing Lerak (Sapindus rarak De Candole). Media Peternakan. 32:63-70.

Behboudi S, Morein B, Villacres-Eriksson MC. 1999. Quillaja saponin formulations that stimulate proinflammatory cytokines elicit a potent acquired cell-mediated immunity. Scand J Immunol. 50:371-7.

Cheeke PR. 2001. Actual and potential applications of Yucca schidigera and Quillaja saponaria saponins in human and animal nutrition. Recent Adv Anim Nut Aust. 13:115-126.

Chung M, Kim N, Long C, Shamon L. 1997. Dereplication of saccharide and polyol constituents of candidate sweet-tasting plants: Isolation of the sesquiterpene glycoside mukurozioside IIb as a sweet principle of Sapindus rarak. Phytochem Anal. 8:49-54.

Efrizanti. 2005. Penggunaan saponin pada ayam broiler: Performan, perubahan, patologis dan pengaruhnya terhadap infeksi Eimeria tenella [Tesis]. [Bogor (Indonesia)]: Institut Pertanian Bogor.

El-Sadawy AH, El-Khateb RM, Kutkat MA. 2009. A Preliminary in vitro trial on the efficacy of products of Xenorhabdus and Photorhabdus spp. on Eimeria oocysts. Glob Vet. 6:489-494. 
Hamburger M, Slacanin I, Hostettmann K, Dyatmiko W, Sutarjadi, 1992. Acetylated saponin in molluscicidal activity from Sapindus rarak: Unambiguous structure determination by proton nuclear magnetic resonance and quantitative analysis. Phytochem Anal. 3:231-237.

Iskandar T, Murdiati TB, Subekti DT. 2000. Pengaruh pemberian infus jahe merah (Zingiber officinale var Rubra) terhadap koksidiosis sekum pada ayam pedaging. In: Haryanto B, Darminto, Hastiono S, Sutama IK, Partoutomo S, Subandriyo, Sinurat AP, Darmono, Supar, Butar-Butar SO, editors. Prosiding Seminar Nasional Peternakan dan Veteriner. Bogor, 18-19 September 2000. Bogor (Indonesia): Puslitbang Peternakan. p. 525-531.

Jafari MT, Khayamian T, Shaer V, Zarei N. 2007. Determination of Veterinary Drug Residues in Chicken Meat using Corona Discharge Ion Mobility. Spectrom Anal Chim Act. 581:147-153.

Levine ND. 1985. Veterinary Protozoology. 1st ed. Ames (USA): Iowa State University Press.

Pasaribu T, Astuti DA, Wina E, Sumiati, Setiyono A. 2014. Saponin content of Sapindus rarak pericarp affected by particle size and type of solvent, its biological activity on Eimeria tenella oocysts. Int J Poult Sci. 13:347-352.

Shierly MW, Buchell AC, McDonald V, Robert B. 1995. A live attenuated vaccine for the control of avian coccidiosis: Trial in broiler breeder and replacement layer flocks in the United Kingdom. Vet Rec. 137:453-457.

Shierly MW. 1996. Biological principle of lives, attenuated vaccines. Magyar Allatorvosak Lapja. 51:23-29.

Shierly MW, Smith AL, tomley FM. 2005. The biology of avian Eimeria with an emphasis on their control by vaccination. Adv Parasitol. 20:285-330.

Tipu MA, Pasha TN, Ali Z. 2002. Comparative efficacy of salinomycin sodium and Neem fruit (Azadirachta indica) as feed additive anticoccidials in broilers. Int J Poult Sci. 1:91-93.

Wiedosari E, Suhirman S, Sembiring B. 2014. Pengaruh jamu herbal sebagai antikoksidia pada ayam pedaging yang diinfeksi Eiemeria tenenlla. J Littri. 20:9-16.

Williams RB, Carlyle WW, Bond WW, Brown DR. 1999. The efficacy and economic benefits of paracox, a live attenuated anticoccidial vaccine, in commercial trials with standard broiler chickens in the United Kingdom. Int J Parasitol Oxford. 29:341-355.

Wina E, Muetzel S, Hoffmann EM, Makkar HPS, Becker K. 2005. Effect of secondary compounds in forages on rumen microorganisms quantified by $16 \mathrm{~S}$ and $18 \mathrm{~S}$ rRNA In: Applications of gene-based technologies for improving animal production and health in developing countries. Makkar HPS, Viljoen GJ, editors. IAEA-FAO, Springer, Netherlands. p. 397-410. Anim Feed Sci Technol. 121:159-174. 